\title{
Kemitraan Kementrian Agama Kota Batu dan PT Bank BNI Syariah Kota Batu dalam Inovasi Meningkatkan Pelayanan Administrasi Ibadah Haji
}

Novi Indahsari ${ }^{\text {a }}$ *

${ }^{a}$ PT. BNI Syariah Cabang Malang, Jawa Timur, Indonesia

\section{INFORMASI ARTIKEL}

\section{Article history:}

Dikirim tanggal: 15 Mei 2018

Revisi pertama tanggal: 17 Mei 2018

Diterima tanggal: 29 Juni 2018

Tersedia online tanggal: 28 Agustus 2018

Keywords: public private partnership,

kemitraan, ibadah haji, BNI Syariah,

Kementerian Agama, kualitas pelayanan publik

\begin{abstract}
The process of administering haj pilgrimage services organized by the Ministry of Religious Affairs is faced with a process that is still not effective and efficient. In the process of Hajj registration, Calon Jemaah Haji (CJH) must go through four stages of the process performed in two different places. Sistem Tekhnologi dan Komputerisasi Haji Terpadu (SISKOHAT) had used as "jantung" service, which in the process has always been innovated to correct the deficiencies. This study aims to describe and analyze the public response to the quality of services provided with partnerships established between the Ministry of Religious Affairs Batu City and PT Bank BNI Syariah Batu City. The quality of the Hajj service is better perceived by the community in the presence of established partnerships and new innovations created, but the partnership has not reached the joint service stage "satu atap".
\end{abstract}

\section{INTISARI}

Proses penyelenggaraan pelayanan administrasi ibadah haji yang diselenggarakan oleh Kementerian Agama dihadapkan pada proses yang masih belum efektif dan efisien. Pada proses pendaftaran haji, Calon Jamaah Haji (CJH) harus melalui empat tahap proses yang dilakukan didua tempat yang berbeda. Sistem Teknologi dan Komputerisasi Haji Terpadu (SISKOHAT) diguanakan sebagai "jantung" pelayanan, yang dalam prosesnya selalu dilakukan inovasi untuk memperbaiki kekurangan. Penelitian ini bertujuan untuk mendeskripsikan dan menganalisis respon masyarakat terhadap kualitas pelayanan yang diberikan dengan kemitraan yang terjalin antara Kementerian Agama Kota Batu dan PT Bank BNI Syariah Kota Batu. Kualitas pelayanan ibadah haji dirasakan lebih baik oleh masyarakat dengan adanya kemitraan yang terjalin dan inovasi baru yang diciptakan, namun kemitraan yang terjalin belum sampai pada tahap joint service "satu atap".

2018 FIA UB. All rights reserved.

\section{Pendahuluan}

Kementerian Pendayagunaan Aparatur Negara (KEPMENPAN) Nomor 63 Tahun 2003 Tentang
Pedoman Umum Penyelenggaraan Pelayanan Publik mendefinisikan pelayanan publik sebagai "Segala kegiatan pelayanan yang dilaksanakan oleh penyelenggara pelayanan publik sebagai upaya

* Corresponding author. Tel.: +62-811-3037-172; e-mail: novindahsari8808@gmail.com 
pemenuhan kebutuhan penerima pelayanan maupun pelaksanaan ketentuan perundang-undangan". Penyelenggara pelayanan publik adalah instansi pemerintah yang meliputi satuan kerja/ satuan organisasi Kementerian, Departemen, Lembaga Pemerintah Non Departemen, Kesekretariatan Lembara Tertinggi dan Tinggi Negara, dan Instansi Pemerintah lainnya, baik Pusat maupun Daerah termasuk Badan Usaha Milik Negara, Badan Hukum Milik Negara dan Badan Usaha Milik Daerah.

Dalam rangka penyelenggaraan pelayanan kepada masyarakat untuk ibadah haji, Kementerian Agama Republik Indonesia lembaga negara yang memiliki tugas dan wewenang dalam pelayanan publik penyelenggaran ibadah haji kepada masyarakat. Pelayanan yang diberikan oleh Kementerian Agama dalam penyelenggaraan ibadah haji meliputi pelayanan administrasi ibadah haji, pembinaan bimbingan ibadah haji, perlindungan ibadah haji, pelaksanaan ibadah haji dan pasca pelaksanaan ibadah haji. Dalam penyelenggaraan pelayanan administrasi, Kementerian Agama bekerja sama dengan Bank Syariah (organisasi swasta) sebagai Bank Penerima Setoran Biaya Ibadah Haji (BPS BPIH).

Penyelenggaraan pelayanan publik yang dilakukan oleh pemerintah masih pada sistem pemerintahan yang belum efektif dan efisien. Kualitas pelayanan publik merupakan salah satu parameter keberhasilan birokrasi. Pelayanan yang berkualitas merupakan harapan masyarakat karena pelayanan merupakan hak yang harus diperolehnya. Namun pada kenyataanya masih banyak keluhan dan pengaduan dari masyarakat baik secara langsung maupun melalui media massa. Salah satu lembaga negara yang mengawasi mengenai pelayanan publik di Indonesia adalah Ombudsman Republik Indonesia. Indikasi pelayanan publik yang masih buruk dapat dilihat dari banyaknya pengaduan/ laporan masyarakat.

Dalam sebuah laporan jumlah laporan masyarakat di seluruh Indonesia yang diterima dari tahun 2010 sampai 2014 sebanyak 17.063, dari data tersebut dapat dilihat adanya peningkatan laporan masyrakat setiap tahunnya, terutama di Tahun 2014 terdapat 6.677 laporan yang masuk di Ombudsman RI (2016) pelayanan publik di Indonesia dihadapkan pada pluralitas yang sangat tinggi dalam banyak aspek kehidupan masyarakat. Karakteristik sosial budaya, kemajuan sosial ekonomi, dan kondisi lingkungan yang berbeda-beda antar kelompok masyarakat menuntut jenis kebutuhan dan manajemen pelayanan yang berbeda-beda.

Peningkatan kualitas pelayanan publik yang dilakukan pemerintah, salah satunya dengan melakukan kemitraan atau kerjasama dengan lembaga swasta atau non pemerintah dalam berbagai bidang, baik dalam hal pelayanan administratif, pelayanan jasa ataupun pelayanan akan penyediaan barang. Seperti halnya dalam pelayanan ibadah haji di Indonesia. Pada awalnya tugas pelayanan ini ditangani sendiri oleh pemerintah, namun saat ini Kementerian Agama bekerja sama dengan Bank Syariah melakukan tugas bersama untuk memberikan pelayanan kepada masyarakat.

Kementerian Agama dan PT Bank Negara Indonesia (BNI) Syariah sebagai BPS BPIH menjalin kemitraan dalam rangka meningkatkan kualitas pelayanan administrasi ibadah haji. Melalui inovasiinovasi yang berkelanjutan diharapkan segala kendala dan kekurangan manajemen administrasi yang selama ini terselenggara dapat teratasi. PT Bank BNI Syariah menciptakan produk dan layanan yang mengedepankan uniqueness dari prinsip syariah dan kebutuhan nyata dari masyarakat. Pelayanan administrasi ibadah haji yang berkualitas kepada masyarakat juga menjadi salah satu tugas utama dari PT Bank BNI Syariah.

Dalam penyelenggaraan pelayanan ibadah haji di Indonesia, Pemerintah melalui Kementerian Agama Republik Indonesia pada tahun 1990 meluncurkan sebuah inovasi pelayanan yaitu Sistem Informasi dan Komputerisasi Haji Terpadu (SISKOHAT) yang kini menjadi "jantung" bagi pelayanan jemaah haji, karena seluruh proses pengolahan data untuk kepentingan pembuatan paspor, administrasi data kesehatan jamaah, penerbangan pemberangkatan dan pemulangan, perbankan dan biodata calon jemaah haji mengacu pada sistem komputer terpadu tersebut. Sistem tersebut digunakan sebagai "cross check" data keuangan di Bank Penerima Setoran Bukti Pendaftaran Haji (BPS BPIH) dan jumlah data calon haji yang diberangkatan. Inovasi layanan berupa SISKOHAT sendiri merupakan perwujudan dari adanya kemitraan yang terjalin oleh Kementerian Agama dan BPS BPIH.

Namun tidak dipungkiri ada sejumlah kendala dan kekurangan dalam proses pelayanan tersebut. Dalam beberapa hal masyarakat masih mengeluhkan pelayanan administrasi haji yang diberikan masih kurang optimal. Kemitraan yang terjalin antara Kementerian Agama dan PT Bank BNI Syariah saat ini, belum bisa mengatasi permasalahan pelayanan yang kurang efektif dan efisien. Dapat dicontohkan ketika nasabah akan melakukan pendaftaran haji, calon jamaah yang akan melakukan pendaftaran haji sebagai tahapan awal dalam pendaftaran, harus melalui tahapan yang panjang. Dikarenakan calon jamaah haji harus "mondar-mandir" dari kantor kementerian Agama dan ke Bank BPS BPIH sampai dengan empat kali untuk proses awal pendaftaran haji.

Pelayanan publik merupakan hak semua warga negara Indonesia, maka birokrasi pelayanan publik 
memiliki kewajiban untuk mengembangkan manajemen pelayanan yang mampu menjamin untuk semua warga tanpa kecuali untuk dapat mengakses pelayanan publik. Warga Indonesia memiliki status sosial ekonomi, tempat tinggal, etnis, dan kondisi fisik yang berbeda-beda sehingga mereka tidak memiliki kemampuan yang sama untuk mengakses pelayanan publik. Karena itu semestinya sudah menjadi tugas dari birokrasi pemerintah untuk meningkatkan kapasitas mereka yang tertinggal dan terpinggirkan agar mereka memiliki kesetaraan akses dengan warga lainnya. Dengan kata lain birokrasi pemerintah harus membuat pelayanan yang diselenggarakannya dapat diakses oleh semua orang secara sama, apapun kondisi dan kendala mereka.

Oleh karena itu menarik untuk dilakukan penelitian lebih mendalam mengenai kemitraan yang terjalin antara Kementerian Agama dan PT Bank BNi Syariah dalam penyelenggaraan pelayanan administrasi ibadah haji. Dimana didalam kemitraan tersebut terdapat sebuah inovasi pelayanan yang bertujuan untuk meningkatkan kualitas pelayanan administrasi ibadah haji di Indonesia. Tidak dipungkiri diantara kedua lembaga ini memiliki tujuan organisasi yang berbeda secara mendasar, namun dalam hal ini keduanya dituntut untuk bisa menjalin sinergi yang baik dalam penyelenggaraan pelayanan kepada masyarakat. Bahwa negara wajib mengelola sumber daya yang dimiliki dan mengalokasikan (dalam bentuk pelayanan publik dan subsidi). Disamping pelayanan oleh pemerintah tidak bersifat mencari laba (non-profit oriented). Sementara pihak swasta dalam mengelola sumber daya ekonomi adalah demi meraih keuntungan (profit oriented).

Berdasarkan uraian yang telah dipaparkan di atas, maka yang menjadi rumusan masalah dalam penelitian ini adalah:

a) Bagaimanakah kemitraan yang terjalin antara Kementerian Agama Kota Batu dan PT Bank BNI Syariah Kota Batu dalam penyelenggaraan pelayanan administrasi ibadah haji?; dan

b) Bagaimanakah penerapan inovasi pelayanan administrasi ibadah haji dalam meningkatkan kualitas pelayanan administrasi haji?

\section{Teori}

\subsection{Kemitraan Sektor Publik dan Swasta (Public Private Partnership)}

Public Private Partnership (PPP) atau Kemitraan Pemerintah Swasta (KPS) dapat diterjemahkan sebagai "Sebuah perjanjian kontrak swasta dan pemerintah, yang keduanya bergabung bersama dalam sebuah kerjasama untuk menggunakan keahlian dan kemampuan masingmasing untuk meningkatkan pelayanan kepada publik dimana kerjasama tersebut dibentuk utnuk menyediakan kualitas pelayanan terbaik dengan biaya yang optimal untuk publik". Dalam pengertian lain, PPP merupakan kemitraan antara pemerintah dan swasta yang melibatkan investasi yang besar. Untuk menciptkan sebuah hubungan yang sukses maka sangat penting untuk memahami tujuan dan kepentingan dari masingmasing pelaku dalam PPP.

Dari definisi yang sederhana dan bersifat umum ini, kemitraan melibatkan bentuk kerjasama yang lebih dari sekedar kontrak kerjasama. Kemitraan melibatkan kerjasama antara pemerintah dan swasta yang lebih intensif dan interaktif, yang masing-masing memiliki independensi tetapi juga memiliki komitmen untuk mewujudkan tujuan bersama. Menurut Sumarto (2009) mendefinisikan kemitraan sebagai sebuah hasil hubungan yang terjadi antara pemerintah dan, atau sektor swasta dalam rangka mencapai suatu tujuan yang berdasa pada prinsip kesetaraan dan kemandirian. Kemitraan dapat diwujudkan dalam bentuk suatu kontrak ataupun tanpa kontrak. Berikut dijelaskan karakteristik dari kemitraan antara pemerintah dan swasta Lienhar dalam Mahmudi (2015):

a) Kerjasama melibatkan setidak-tidaknya satu lembaga pemerintah dan satu lembaga swasta;

b) Kerjasama dilakukan untuk mencapai tujuan bersama atau secara timbal balik kompatibel dan saling melengkapi;

c) Bersifat kompleks dan membutuhkan koordinasi yang intensif;

d) Kerjasama dilakukan dalam rangka melakukan procurement atau pelaksanaan tugas tertentu;

e) Memiliki tugas tertentu;

f) Penyatuan, pemanfaatan, dan startegi dari sumberdaya pemerintah dan swasta;

g) Berbagi resiko; dan

h) Perolehan dalam efisiensi dan efektivitas.

Menurut Rosen (1993:218) pengaturan kerjasama (Form of Cooperation Arrangements) terdiri atas beberapa bentuk, yaitu sebagai berikut:

a) Consortia: Pengaturan kerjasama dalam sharing sumberdaya, karena lebih mahal bila ditanggung sendiri-sendiri; misalnya pendirian perpustakaan dimana sumberdaya seperti buku-buku, dan pelayanan lainnya, dapat digunakan bersama-sama oleh mahasiswa, pelajar dan masyarakat publik, dari pada masing-masing pihak mendirikan sendiri karena lebih mahal;

b) Joint Purchasing: Pengaturan kerjasama dalam melakukan pembelian barang agar dapat menekan biaya karena skala pembelian lebih besar;

c) Equipment Sharing: Pengaturan kerjasama dalam sharing peralatan yang mahal, atau yang tidak setiap hari digunakan; 
d) Cooperative construction: Pengaturan kerjasama dalam mendirikan bangunan, seperti pusat rekreasi, gedung perpustakaan, lokasi parkir, gedung pertunjukan, dan sebagainya;

e) Joint Services: Pengaturan kerjasama dalam memberikan pelayanan publik, seperti pusat pelayanan satu atap yang dimiliki bersama, dimana setiap pihak mengirim aparatnya untuk bekerja dalam pusat pelayanan tersebut;

f) Contract Services: Pengaturan kerjasama dimana pihak yang satu mengontrak pihak yang lain untuk memberikan pelayanan tertentu, misalnya pelayanan air minum, persampahan, dsb. Jenis pengaturan ini lebih mudah dibuat dan dihentikan, ditransfer ke pihak yang lain; dan

g) Pengaturan lainnya: Pengaturan kerjasama lain dapat dilakukan selama dapat menekan biaya, misalnya membuat pusat pendidikan dan pelatihan (DIKLAT), fasilitas pergudangan, dan sebagainya.

Lebih lanjut menurut Rosen dalam Keban (2009) bentuk-bentuk perjanjian (forms of agreement) dibedakan atas, yaitu sebagai berikut:

a) Handshake Agreement, yaitu pengaturan kerjasama yang tidak didasarkan atas perjanjian tertulis; dan

b) Written Agreements, yaitu pengaturan kerjasama yang didasarkan atas perjanjian tertulis.

\subsection{Inovasi Sektor Publik}

Inovasi secara umum dipahami dalam konteks perubahan perilaku. Inovasi biasanya erat kaitannya dengan lingkungan yang berkarakteristik dinamis dan berkembang. Menurut Rogers dalam Suwarno (2008), menjelaskan inovasi adalah sebuah ide, praktek, atau objek yang dianggap baru oleh individu satu unit adopsi lainnya. Pengertian dari sumber lain menyebutkan bahwa inovasi adalah kegiatan yang meliputi seluruh proses menciptakan dan menawarkan jasa atau barang baik yang sifatnya baru, lebih baik atau lebih murah dibandingkan dengan yang tersedia sebelumnya. Inovasi dapat berupa produk atau jasa yang baru, teknologi proses produksi yang baru, sistem struktur dan administrasi baru atau rencana baru bagi anggota organisasi.

Dengan merujuk pada pengertian diatas, maka inovasi tidak akan bisa berkembang dalam status quo. Secara umum dapat disimpulkan bahwa inovasi mempunyai atribut sebagai berikut:

a) Relative advantage atau keuntungan relatif;

b) Compability atau kesesuaian;

c) Complexity atau kerumitan;

d) Triability atau kemungkinan dicoba; dan

e) Observability atau kemudahan diamati.

Ada beberapa bentuk inovasi yang dapat diterapkan dalam sebuah organisasi sektor publik. inovasi yang berhasil merupakan kreasi dan implementasi dari proses, produk, layanan dan metode pelayanan baru yang merupakan hasil pengembangan nyata dalam hal efisiensi, efektivitas atau kualitas hasil (Mulgan \& Albury dalam Muluk, 2008:44). Dalam tipologi inovasi terdapat lima indikator diantaranya, yaitu sebagai berikut:

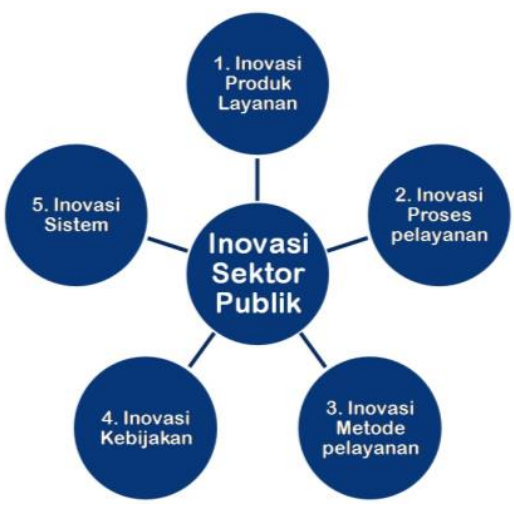

Gambar 1 Tipologi Inovasi

Sumber: Mulgan \& Albury dalam Muluk (2008:44)

Adapun keterangan dalam gambar tersebut adalah sebagai berikut:

a) Inovasi Produk, yaitu perubahan bentuk design produk/ layanan;

b) Inovasi Proses Pelayanan, yaitu pembaruan kualitas yg berkelanjutan;

c) Inovasi Metode Pelayanan, yaitu cara baru dalam memberikan pelayanan;

d) Inovasi Kebijakan, yaitu perumusan visi, misi, tujuan dan strategi baru beserta alasannya yang berangkat dari realitas yang ada; dan

e) Inovasi Sistem, yaitu perubahan dalam tata kelola pemerintahan (changes in governance).

\subsection{Reformasi Administrasi Publik}

Menurut Caiden (1970) menyatakan refomasi administrasi sebagai "The Artificial inducement of administrative transformation againts resistance"; dimana dapat diartikan bahwa reformasi adalah sesuatu yang memang secara sengaja dibuat oleh manusia yang didalamnya terdapat proses-proses atau tahapan-tahapan yang harus dilalui atau dibuat. Lee dan Samonte (Nasucha, 2004), menyatakan bahwa reformasi administrasi merupakan perubahan atau inovasi secara sengaja dibuat dan diterapkan utuk menjadikan sistem administrasi tersebut sebagai suatu agen perubahan sosial yang lebih efektif dan sebagai suatu instrumen yang dapat lebih menjamin adanya persamaan politik, keadaan sosial dan pertumbuhan ekonomi.

Dror (1970), melihat tujuan administrasi berorientasi jamak dengan mengklasifikasikan tujuan reformasi kedalam enam kelompok, tiga bersifat intra- 
administrasi yang ditujukan menyempurnakan administrasi internal, meliputi sebagai berikut:

a) Efisiensi administrasi, dalam arti hemat biaya, yang dapat dicapai melalui penyederhanaan formulir, perubahan prosedur, penghilangan duplikasi, dan kegiatan organisasi metode yang lain;

b) Penghapusan kelemahan administrasi, seperti korupsi, pilih kasih dalam sistem politik, dan sebagainya; dan

c) Pengenalan dan penerapan sistem merit, pemrosesan data melalui sistem informasi yang otomatis, peningkatan penggunaan pengetahuan ilmiah, dan sebagainya.

Sedangkan yang tiga lainnya berkenaan dengan peran masyarakat di dalam sistem administrasi, meliputi antara lain sebagai berikut:

a) Menyesuaikan sistem administrasi terhadap meningkatnya keluhan masyarakat;

b) Mengubah pembagian pekerjaan antara sistem administrasi dan sistem politik, seperti meningkatkan otonomi profesional dari sistem administrasi dan meningkatkan pengaruhnya pada suatu kebijaksanaan; dan

c) Mengubah hubungan antara sistem administrasi dan penduduk, misalnya melalui relokasi pusa-pusat kekuasaan (desentralisasi).

\subsection{Penyelenggaraan Pelayanan Pubik}

Dalam Setyaningrum (2009:1-2) disebutkan bahwa Lembaga Administrasi Negara mengartikan Pelayanan Umum sebagai "segala bentuk kegiatan yang dilaksanakan oleh Instansi Pemerintahan dipusat dan daerah, dan di lingkungan BUMN/ BUMD dalam bentuk barang dan/ atau jasa, baik dalam pemenuhan kebutuhan masyarakat maupun dalam rangka pelaksanaan ketentuan peraturan perundang-undangan”. Senada dengan pengertian tersebut, Departemen Dalam Negeri menyebutkan bahwa pelayanan publik adalah pelayanan Umum dan mendefinisikan sebagai suatu proses bantuan kepada orang lain dengan cara-cara tertentu yang memerlukan kepekaan dan hubungan interpersonal tercipta kepuasan dan keberhasilan. Setiap pelayanan menghasilkan produk, baik berupa barang dan jasa.

Sedangkan Agus Dwiyanto dalam Abdullah (2014) menyatakan bahwa publik sebagai kegiatan pelayanan yang dilaksanakan oleh penyelenggara pelayanan publik sebagai upaya pemenuhan kebutuhan publik dan pelaksanaan ketentuan peraturan perundang-undangan. Dari beberapa pengertian pelayanan dan pelayanan publik yang diuraikan tersebut, dalam konteks pemerintah daerah, pelayanan publik dapat disimpulkan sebagai pemberian layanan atau melayani keperluan orang atau masyarakat dan/ atau organisasi lain yang mempunyai kepentingan pada organisasi itu, sesuai dengan aturan pokok dan tata cara yang ditentukan dan ditujukan untuk memberikan kepuasan kepada penerima pelayanan.

Dengan demikian, terdapat tiga unsur penting dalam pelayanan publik, yaitu unsur pertama adalah organisasi pemberi (penyelenggara) pelayanan, yaitu pemerintah; unsur kedua, adalah penerima layanan (pelanggan), yaitu orang atau masyarakat atau organisasi yang berkepentingan; dan unsur ketiga, adalah kepuasan yang diberikan dan/ atau diterima oleh penerima layanan (pelanggan) (Agus Dwiyanto dalam Abdullah, 2014).

Dalam memberikan pelayanan publik, instansi penyedia pelayanan publik harus memperhatikan kriteria pemilihan kualitas pelayanan yang selalu digunakan oleh konsumen. Suatu produk dapat dinilai berkualitas apabila dapat memberi kepuasan sepenuhnya kepada konsumen yakni sesuai dengan apa yang diharapkan konsumen atas suatu produk. Menurut Zeithmal, Parasuraman dan Berry dalam Dwiyanto (2004:145); kriteria yang dimaksud antara lain, sebagai berikut:

a) Tangible, yaitu bukti fisik dari jasa yang berupa fisik, peralatan yang digunakan dan representasi fisik dan jasa;

b) Reliability, mencangkup dua hal pokok yaitu konsistensi kerja (performance) dan kemampuan untuk dipercaya (dependability). Dalam hal ini perusahaan pemberi jasanya secara tepat sejenak saat pertama dalam memenuhi janjinya;

c) Responsiviness, yaitu kemauan atau kesiapan para karyawan untuk memberikan jasa yang dibutuhkan oleh pelanggan;

d) Competence, setiap karyawan dalam perusahaan jasa tersebut memiliki keterampilan dan pengetahuan yang dibutuhkan agar dapat memberikan jasa tersebut;

e) Courtesy, meliputi sikap sopan santun, respect, perhatian, dan keramahtamahan para contact personel;

f) Credibility, yaitu sikap jujur dan dapat dipercaya, kredibilitas mencangkup nama perusahaan, reputasi perusahaan, karakteristik contact personal dan interaksi dengan perusahaan;

g) Security, aman dari bahaya dan resik keragu-raguan. Aspek ini meliputi keamanan secara fisik, kemampuan finansial, serta kerahasian;

h) Access, yaitu kemudahan untuk dihubungi atau ditemui. Hal ini berarti lokasi, fasilitas jasa mudah dijangkau, waktu menunggu yang tidak terlalu lama, saluran komunikasi mudah untuk dihubungi;

i) Communication, memberikan informasi kepada pelanggan dalam bahasa yang dapat dipahami serta melalui mendengarkan saran dan keluhan pelanggan; dan 
j) Understanding the customers, yaitu usaha untuk mengetahui kebutuhan pelanggan.

\section{Metode Penelitian}

\subsection{Jenis Penelitian}

Dengan memperhatikan rumusan masalah yang terkait dengan topik yang sedang diteliti, penelitian ini termasuk dalam penelitian deskriptif dengan pendekatan kualitatif. Dalam penelitian ini mendeskripsikan tentang proses penyelenggaraan pelayanan administrasi pendaftaran ibadah haji dan inovasi yang telah dilakukan dengan tujuan dalam mencari fakta dan fenomena yang dikaji dapat secara mendalam, menyeluruh dan alamiah tanpa adanya keberpihakan peneliti.

\subsection{Fokus Penelitian}

Berdasarkan pertimbangan hal-hal diatas maka yang menjadi fokus penelitian dalam penelitian ini, yaitu sebagai berikut:

a) Kemitraan Kementerian Agama Kota Batu dan PT

Bank BNI Syariah Kota Batu dalam penyelenggaraan pelayanan administrasi ibadah haji yang meliputi:

- Jenis kemitraan yang terjalin antara Kementerian Agama Kota Batu dengan PT Bank BNI Syariah Kota Batu; dan

- Bentuk pelayanan yang dimitrakan Kementerian Agama Kota Batu dalam penyelenggaraan pelayanan administrasi ibadah haji.

b) Penerapan Inovasi dalam meningkatkan kualitas pelayanan administrasi ibadah haji:

- Atribut inovasi dalam mendukung pelayanan administrasi ibadah haji;

- Jenis Inovasi yang diberikan Kementerian Agama Kota Batu dan PT Bank BNI Syariah Kota Batu; dan

- Analisa kualitas pelayanan yang diberikan Kementerian Agama Kota Batu dan PT Bank BNI Syariah Kota Batu.

\section{Hasil Penelitian dan Pembahasan}

\subsection{Kemitraan Kementerian Agama dengan PT Bank BNI Syariah dalam Penyelenggaraan Pelayanan Administrasi Ibadah Haji}

Dalam sebuah kemitraan, paling sedikitnya terdapat dua orang atau lembaga (stakeholder) yang terlibat. Dalam pelayanan administrasi ibadah haji, khususnya dalam pengelolaan biaya haji, maka pertama untuk stakeholder adalah pemerintah yaitu Kementerian Agama bekerja sama dengan PT Bank BNI Syariah. Kedua, stakeholder yang terlibat memiliki kapasitas yang berbeda sehingga dengan adanya kerjasama ini bisa saling melengkapi.

Kementerian Agama dan PT Bank BNI Syariah menjalin kemitraan berdasarkan Peraturan Menteri Agama No 30 Tahun 2013 tentang Bank Penerima Setoran Biaya Penyelenggaraan Ibadah Haji (BPS BPIH) pada pasal 1 ayat (3) menyatakan bahwa Bank Penerima Setoran BPIH yang selanjutnya disingkat BPS BPIH adalah bank syariah dan atau bank umum nasional yang memiliki layanan syariah.

Penetapan bank syariah sebagai BPS BPIH tentunya harus memenuhi kriteria khusus. Berdasarkan Peraturan Menteri Agama No. 24 Tahun 2016 tentang Perubahan Peraturan Menteri Agama No 30 Tahun 2013 tentang Bank Penerima Setoran Biaya Penyelenggaraan Ibadah Haji. Kemitraan yang terjalin antara Kementerian Agama dan PT Bank BNI Syariah sejak diterbitkannya Keputusan Menteri Agama No. 241 Tahun 2013 Mengenai PT Bank BNI Syariah Sebagai BPS BPIH. Bank syariah yang telah ditunjuk wajib menandatangai perjanjian kerjasama.

Kemitraan yang terjalin sebagai bentuk penyelenggaran pelayanan publik, salah satunya adalah pelayanan yang bersifat administrasi dan jasa. Kementerian Agama menyediakan beberapa pelayanan yang terkait dengan penyelenggaraan pelayanan ibadah haji. Salah satu bentuk pelayanan yang dimitrakan oleh Kemitraan Agama dengan BPS BPIH adalah pelayanan pendaftaran haji sebagaimana yang telah dilaksanakan oleh Kementerian Agama Kota Batu dan PT Bank BNI Syariah Kota Batu.

Konsep kemitraan antara pemerintah dan swasta dalam beberapa literatur sering didefinisikan secara berbeda-beda. Menurut Sumarto (2009:16) mendefinisikan kemitraan sebagai sebuah hasil hubungan yang terjadi antara pemerintah dan, atau sektor swasta dalam rangka mencapai suatu tujuan yang berdasa pada prinsip kesetaraan dan kemandirian.

Dengan definisi diatas maka dalam kemitraan yang terjalin antara kemitraan Kementeriaan Agama Kota Batu dan PT Bank BNI Syariah Kota Batu sudah memenuhi persyaratan terbentuknya suatu kemitraan. Dimana senada dengan yang diungkapkan oleh Sumarto (2009) kemitraan yang terjalin sebagai hasil hubungan dengan prisip kesetaraan dan kemandirian dengan tujuan menyelenggarakan pelayanan administrasi ibadah haji di Indonesia yang lebih berkualitas kepada masyarakat.

Berdasarkan teori yang ada, maka dapat dikategorikan kemitraan yang terjalin antara Kementerian Agama Kota Batu dan PT Bank BNI Syariah Kota Batu yaitu terjadi pada level collaborating/ kolaborasi. Dalam tingkatan ini kedua belah pihak saling bertukar informasi terkait informasi yang dibutuhkan masing-masing pihak, kegiatan yang 
dilakukan bersama, membagi masing-masing sumberdaya, dan meningkatkan kapasitas sumberdaya diantara pihak-pihak yang terlibat. Analisa yang menjadi pembeda tipe hubungan kolaborasi dengan tipe hubungan yang lain adalah terletak pada sisi pemberdayaan sumberdaya menjadi kompeten dan mengambil keahlian khusus akibat adanya sharing resources yang sudah terjadi sebelumnya.

Bentuk kerjasama kolaborasi bersifat formal dan masing-masing pihak yang terlibat memiliki komitmen yang luas dan tingkat kepercayaan yang sangat tinggi. Seperti kemitraan yang terjalin antara Kementerian Agama dan PT Bank BNI Syariah sebagai BPS BPIH yang tertuang dalam Perjanjian Kerjasama dalam kurun waktu tiga tahun dan dapat diperpanjang dengan kesepakatan bersama.

\subsection{Penerapan Inovasi dalam Meningkatkan Kualitas Pelayanan Administrasi Ibadah Haji}

Inovasi yang dilakukan oleh Kementerian Agama yaitu Sistem Komputerisasi Haji Terpadu (SISKOHAT) yang mana sistem ini digunakan oleh Kementerian Agama dan PT Bank BNI Syariah sebagai BPS BPIH untuk melakukan pelayanan pendaftaran ibadah haji di Indonesia. Dengan adanya sistem yang terintergrasi dan terpusat memperkecil kemungkinan kesalahan dalam pengisian data atau melakukan kecurangan dalam penetapan nomor porsi calon jamaah haji. SISKOHAT juga membantu mempercepat proses setoran awal biaya pendaftaran haji pada bank BPS BPIH yang telah ditetapkan hingga mendapatkan nomor porsi haji. Sistem pendataan berlangsung secara online dan realtime dengan Bank BPS BPIH yang ditunjuk dan Kementerian Agama diselurah daerah di Indonesia dengan pusat komputer di Kementerian Agama Pusat.

Proses pelayanan yang diberikan oleh Kementerian Agama saat ini masih menemui beberapa kekurangan. Dalam proses pendaftaran ibadah haji dengan menggunakan SISKOHAT Gen. 2 Versi 2, calon jamaah haji diwajibkan untuk datang sendiri ke kantor Kementerian Agama dan BPS BPIH sampai dengan empat kali. Proses yang berlangsung kurang efektif dan efisien bila ditinjau dari segi waktu dan biaya.

Oleh karena itu guna memperbaiki permasalahan yang ada maka diciptakannya Inovasi SISKOHAT Gen. 2 Versi 3 secara nyata merubah proses pendaftaran haji menjadi lebih sederhana dan cepat. Alur proses terpangkas menjadi dua tahapan saja. Dengan adanya inovasi baru tersebut, tentunya juga harus didukung dengan pemberdayaan sumberdaya manusia (SDM) secara memadai dan profesional dan sarana dan prasarana yang memadai agar proses pelayanan dapat berjalan optimal. Semua terintegrasi menjadi satu kesatuan yang tercipta guna meningkatkan kualitas pelayanan administrasi ibadah haji.

Sebagaimana definisi yang diberikan oleh Rogers dalam Suwarno (2008) yang menjelaskan inovasi adalah sebuah ide, praktek, atau objek yang dianggap baru oleh individu suatu unit adopsi lainnya. Berdasarkan definisi tersebut maka, Rogers menyatakan terdapat sedikitnya lima atribut dalam sebuah inovasi, yaitu sebagai berikut: a) Relative Advantage atau Keuntungan Relatif

Sebuah keuntungan apabila disebut sebagai keuntungan relatif adalah sejauh mana inovasi dianggap lebih baik daripada produk yang diganti. Sistem Informasi dan Komputerisasi Haji Terpadu atau SISKOHAT Gen. 2 Versi 3 memiliki keuntungan lebih jika dibandingkan dengan SISKOHAT Gen. 2 Versi 2. Penggunaan SISKOHAT Gen.2 Versi 3 dapat memangkas alur proses pelayanan administrasi pendaftaran haji. Jika dahulu calon jamaah haji harus mondar-mandir sebanyak empat kali dari Kantor Kementerian Agama ke BPS BPIH, dengan adanya inovasi baru ini Calon Jamaah Haji cukup satu kali datang Ke BPS BPIH dan satu kali ke Kantor Kementerian Agama. Inovasi tersebut cukup memberikan raasa kepuasan tersendiri bagi calon pendaftar haji karena mereka menganggap tidak memerlukan mobilitas yang tingi untuk melakukan pendaftaran haji maupun umroh.

b) Compability atau Kesesuaian

Inovasi pelayanan sektor publik harus memiliki sifat kompatibel atau sesuai dengan inovasi yang digantinya. Dengan adanya SISKOHAT Gen. 2 Versi 3 bukan menggatikan sepenuhnya sistem yang sudah ada, tetapi inovasi baru itu muncul untuk memperbaiki dan melengkapi versi yang sebelumnya. Segala kekurangan yang terdapat pada versi sebelumnya sudah bisa teratasi dengan munculnya SISKOHAT Gen. 2 Versi 3 saat ini.

c) Complexity atau Kerumitan

Sifat inovasi yang baru, maka inovasi mempunyai tingkat kerumitan yang boleh jadi lebih rumit dengan inovasi sebelumnya. Namun demikian, karena sebuah inovasi karena inovasi menawarkan cara yang lebih baik, maka tingkat kerumitan yang terjadi tidak menjadi masalah yang berarti. Dalam SISKOHAT Gen. 2 Versi 3 tingkat kerumitan dalam pengaplikasiannya bisa dikatakan lebih tinggi. Semakin tinggi kesulitan tingkat pengaplikasiannya terletak pada petugas BPS BPIH dalam hal ini PT Bank BNI Syariah. Dikarenakan screening data kelengkapan sampai dengan penginputan data Calon Jamaah Haji dilakukan oleh petugas BPS $\mathrm{BPIH}$, yang mana pada prosedur yang lama dilakukan oleh petugas Kementerian Agama.

d) Triability atau Kemungkinan Dicoba

Inovasi hanya bisa diterima apabila telah teruji dan terbukti mempunyai keuntungan atau nilai lebih 
dibandingkan dengan inovasi yang lama. Pengaplikasian SISKOHAT Gen. 2 Versi 3 pada masa sekarang ini masih dalam taraf uji coba. Dalam masa ini akan dilihat sejauh mana kualitas dari inovasi baru tersebut. Walaupun begitu inovasi ini sangat mungkin sekali untuk diaplikasikan karena inovasi itu sendiri tidak merubah total dari sistem yang sudah ada. Sehingga ketika petugas yang mengaplikasikan tidak akan mengalami kesulitan yang berarti ketika memberikan pelayanan kepada masyarakat.

e) Observability atau Kemudahan Diamati

Sebuah inovasi harus dapat diamati, dari segi bagaimana inovasi tersebut berkerja dan menghasilkan sesuatu yang lebih baik. SISKOHAT Gen. 2 Versi 3 dalam pengaplikasiannya dapat dengan mudah diamati mengenai bagaimana sistem tersebut dapat bekerja secara efektif sebagai media pelayanan administrasi ibadah haji di Indonesia. Untuk melihat efektivitas dari inovasi sistem tersebut dapat dilihat dari keluhan yang diberikan oleh masyarakat sebagai penerima layanan. Apakah pelayanan yang didapat sudah sesuai dengan harapan.

Inovasi dalam aktifitas kemitraan sektor publik dan bisnis sehingga dapat dikategorikan sebagai innovative governance pada sektor layanan publik berdasarkan pendapat Muluk (2008:44). Didalam teori tersebut dijelaskan bahwa inovasi yang berhasil merupakan kreasi dan implementasi dari proses, produk, layanan dan metode pelayanan baru yang merupakan hasil pengembangan nyata dalam hal efisiensi, efektivitas atau kualitas hasil. Terdapat lima analisis yang dapat menyimpulkan apakah inovasi tersebut sudah dikatakan sebagai inovasi sektor publik, antara lain sebagai berikut:

a) Inovasi Produk Layanan

Produk layanan yang sekarang ini diberikan oleh Kementerian Agama berkaitan dengan sistem pendaftaran haji dan umroh sudah menerapkan design yang baru yang diberi nama SISKOHAT Gen 2 Versi . Namun perubahan bentuk design ini tidak menyeluruh hanya alurnya saja yang mengalami perubahan namun berdampak rasa kepuasan pada konsumen. Bentuk design yang berubah seperti yang sudah dipaparkan pada hasil penelitian menunjukan bahwa inovasi yang dikeluarkan harus dapat menyederhanakan alur pelayanan yang terkesan berbelit - belit. Karena dengan menyederhanakan alur melalui design layanan sangat akan berdampak pada kefektifitasan layanan. Seperti yang diutarakan oleh Muluk (2008), inovasi pada sektor publik akan berhasil apabila ada dampak layanan yang lebih efektif dalam prosesnya.

b) Inovasi Proses Pelayanan

Proses pembaruan yang terjadi pada sistem pelayanan haji dan umroh selalu diterapkan oleh
Kementerian Agama. Terdapat dua pengertian dalam pembaruan itu sendiri. Pertama pembaruan diartikan sebagai sebuah proses, perbuatan, atau cara untuk memperbaharui sesuatu. Kedua inovasi (pembaruan) dapat diartikan sebagai suatu penemuan yang baru yang belum pernah ada sebelumnya. Sistem pendaftaran SISKOHAT Gen 2 Versi 3 yang digagas oleh Kementerian Agama merupakan jenis pembaruan berorientasi pada proses dan cara memperbarui sesuatu. Pembaharuan tersebut terletak pada sistem keamanan, kehematan waktu, dan alur yang semakin ringkas dari sistem sebelumnya.

c) Inovasi Metode Pelayanan

Dalam pelayanan pendaftaran haji secara makro tidak merubah metode dalam memberikan pelayanan yang menggandeng organisasi bisnis agar lebih profesional dan akuntabel. Metode ini belum diterapkan sebelumnya karena metode sebelumnya lebih birokratif dan berbelit - belit.

d) Inovasi Kebijakan

Inovasi kebijakan yang dimaksud adalah adanya inisiatif dan arah kebijakan baru. Fokus dari inovasi yang mempengaruhi proses pembuatan kebijakan harus dapat memfasilitasi peran serta warga masyarakat atau stakeholder terkait. Berangkat dari permasalahan kebijakan Peraturan Menteri Agama Nomor 14 Tahun 2012 tentang Penyelenggaraan Haji Regular; Kementerian Agama banyak mendapat laporan tetang persyaratan pendaftaran haji yang terlalu banyak, alur pendaftaran yang berbelit, dan sistem kecurangan yang tidak bisa dibendung. Hal tersebut yang melatar belakangi inovasi kebijakan Kementerian Agama tentang pendaftaran dan pelunasan haji regular dan implementasi SISKOHAT Gen 2 Versi 3 yang disempurnakan oleh Peraturan Menteri Nomor 29 Tahun 2015. Kebijakan yang baru tersebut memuat beberapa poin utamanya tentang penyempurnaan persyaratan pendaftaran haji, alur pendaftaran, dan pembatalan haji regular. Adapun hasil temuan dilapangan tersebut menandakan bahwa Kementerian Agama telah menerapkan salah satu tipologi inovasi pemerintahan yaitu perubahan kebijakan.

e) Inovasi Sistem

Inovasi Sistem terjadi dalam sistem penyelenggaraan pelayanan ibadah haji secara parsial, khususnya dalam hal pendaftaran ibadah haji. Kementerian Agama merubah sistem lama yang kurang efektif menjadi lebih praktis dan efektif. Dengan adanya tekhnologi Sistem Komputerisasi Haji Terpadu (SISKOHAT), kerjasama antara Kementerian Agama dan PT Bank BNI Syariah dapat bersinergi dalam memberikan pelayanan pendaftaran ibadah haji. Permasalan yang sebelumnya ada menjadi terpecahkan dan penyelenggaraan pelayan publik menjadi lebih baik 
dan stakeholder yang terlibat lebih bisa merasakan manfaat dari perubahan tersebut.

Inovasi yang dilakukan oleh untuk meningkatkan kualitas pelayanan di Kantor Kementerian Agama Kota Batu menggunakan elaborasi ukuran kualitas pelayanan yang disampaikan oleh Zeithaml, Berry dan Parasurahman (1988) sebagai berikut:

a) Tangible, bukti fisik dari jasa, peralatan yang digunakan dan representasi fisik dan jasa. Bukti fisik untuk mendukung pelayanan di Kantor Kementerian Agama Kota Batu dapat dilihat berdasarkan ketersediaan sarana parkir, gedung, ruang penyerahan berkas dan penginputan data calon jamaah haji dan pencetakan bukti porsi pendaftaran haji. Semua proses pelayanan menggunakan satu sistem komputerisasi terpadu SISKOHAT Gen. 2 Versi 3. Dengan adanya sistem tersebut petugas dapat dengan mudah memberikan pelayanan dengan cepat, efektif dan efisien. Sarana dan prasarana ruang sudah cukup memadai untuk mendukung proses pelayanan;

b) Reliability, yaitu mencangkup dua hal pokok yaitu konsistensi kerja (performance) dan kemampuan untuk dipercaya (dependability). Keefisienan waktu dari pelayanan di kantor Kementerian Agama Kota Batu dapat dikatakan sudah efisien. Dengan adanya inovasi baru SISKOHAT Generasi 2 Versi 3 ini, proses pelayanan yang diberikan saat ini cukup singkat, dari proses pengumpulan berkas, penginputan data sampai dengan pencetakan bukti. Proses tersebut berlangsung pada hari yang sama dan bisa ditunggu, tanpa ada proses datang kembali ke Kantor Kementerian Agama atau BPS BPIH.

c) Responsiviness, yaitu kualitas pelayanan yang dilihat dari kerelaan untuk menolong pengguna pelayanan dan menyelnggarakan pelayanan secara ikhlas. Setalah adanya inovasi SISKOHAT Gen. 2 Versi 3 ini telah memenuhi harapan pengguna layanan akan layanan yang cepat dan mudah;

d) Competence, setiap karyawan dalam perusahaan jasa tersebut memiliki keterampilan dan pengetahuan yang dibutuhkan agar dapat memberikan jasa tersebut. Para petugas di Kementerian Agama Kota Batu dan PT Bank BNI Syariah Kota Batu sudah memiliki kemampuan yang cukup. Pelatihan berkala dilakukan untuk mengembangkan kemampuan petugas;

e) Courtesy, meliputi sikap sopan santun, respect, perhatian, dan keramahtamahan para contact personil. Petugas Kementerian Agama Kota Batu dan PT Bank BNI Syariah selalu menyambut calon jamaah haji dengan senang hati. Melayani "Tamu Allah dengan baik mempunyai nilai ibadah yang besar" menjadi filosofi dan semangat bagi petugas untuk selalu memberikan pelayanan yang terbaik;

f) Credibility, yaitu sikap jujur dan dapat dipercaya, kredibilitas mencangkup nama perusahaan, reputasi perusahaan, karakteristik contact personal dan interaksi dengan perusahaan. Kedua institusi baik Kementerian Agama dan PT Bank BNI Syariah selalu menjaga profesionalitas dan selalu memegang teguh komitmen untuk menjaga kredibilitas petugas dan institusi;

g) Security, aman dari bahaya dan resiko keraguraguan. Aspek ini meliputi keamanan secara fisik, kemampuan finansial, serta kerahasian. Pelayanan administrasi ibadah haji yang diberikan hampir tidak ada resiko bahaya. Kepastian pemberian layanan dan keamanan penyimpanan dana pada Bank sudah dijamin oleh lembaga yang memiliki otoritas;

h) Access, yaitu kemudahan untuk dihubungi atau ditemui. Hal ini berarti lokasi, fasilitas jasa mudah dijangkau, waktu menunggu yang tidak terlalu lama, saluran komunikasi mudah untuk dihubungi. Kementerian Agama dan PT Bank BNI Syariah memberikan berbagai salura media komunikasi online. Adanya proses inovasi yang baru juga mempersingkat tahapan proses sehingga waktu pelayanan lebih singkat;

i) Communication, memberikan informasi kepada pelanggan dalam bahasa yang dapat dipahami serta melalui mendengarkan saran dan keluhan pelanggan. Dalam hal ini petugas di kantor Kementerian Agama Kota Batu telah mampu berkomunikasi dengan baik dengan masyarakat yang berkaitan dengan prosedur pendaftaran, pelunasan ataupun pembatalan haji. Biasanya Kementerian Agama Kota Batu melakukan sosialisasi setiap tahun mengenai pelaksanaan penyelenggaraan ibadah haji. Kementerian Agama Kota Batu juga menjalin kerja sama dengan Kelompok Bimbingan Ibadah Haji di Kota Batu sebagai penghubung informasi kepada calon jamaah yang lokasinya jauh dari Kantor Kementerian Agama Kota Batu; dan

j) Understanding the customers, yaitu usaha untuk mengetahui kebutuhan pelanggan. Dalam hal ini Kementerian Agama selalu melakukan perbaikan dan evaluasi dari pelayanan yang telah diberikan secara berkala. Karena seiring dengan perkembangan sosio-ekonomi masyarakat, maka kebutuhan masyarakat pun juga berkembang.

\section{Kesimpulan}

Berdasarkan hasil penelitian dan analisis, maka dapat ditarik kesimpulan bahwa:

a) Kemitraan yang terjalin antara Kementerian Agama Kota Batu dan PT Bank BNI Syariah Kota Batu, 
yaitu terjadi pada level Collaborating/ kolaborasi. Dalam tingkatan ini kedua belah pihak saling bertukar informasi terkait informasi yang dibutuhkan masing-masing pihak, kegiatan yang dilakukan bersama, membagi masing-masing sumberdaya, dan meningkatkan kapasitas sumberdaya diantara pihakpihak yang terlibat. Kementerian Agama menyediakan beberapa pelayanan yang terkait dengan penyelenggaraan pelayanan ibadah haji. Salah satu bentuk pelayanan yang dimitrakan oleh Kemitraan Agama dengan BPS BPIH adalah pelayanan pendaftaran haji sebagaimana yang telah dilaksanakan oleh Kementerian Agama Kota Batu dan PT Bank BNI Syariah Kota Batu;

b) Inovasi yang dilakukan Kementerian Agama memiliki terdapat lima atribut dalam inovasi ini, yaitu pertama, relative advantage yang tercermin dari pembaharuan SISKOHAT Gen 2 Versi 3 memberikan keuntungan yang lebih efektif dan efisien dalam proses pelayanan pendaftaran haji. Kedua, compability yang tercermin dari inovasi yang dibuat sebagai perbaikan dari inovasi yang sebelumnya. Ketiga, complexity yang tercermin dari peran PT Bank BNI Syariah yang semakin komplek dalam memberikan pelayanan pendaftaran haji. Keempat, triability yang tercermin dari pengaplikasian inovasi ini masih dalam tahap uji coba yang pada masa ini akan dilihat sejauh mana kualitas inovasi baru tersebut. Kelima, observability yang tercermin dari inovasi yang mudah diamati melalui proses pelayanan pendaftaran haji dan langsung dapat memberikan feedback dari pengguna layanan sebagai bahan perbaikan selanjutnya. Inovasi SISKOHAT dikategorikan kedalam jenis Inovasi Teknologi dan Inovasi Proses. Inovasi SISKOHAT diciptakan untuk mengatasi permasalahan yang ada sebelumnya dan dapat dikatakan sebagai innovative governance. Dengan adanya inovasi baru proses pelayanan pendaftaran haji menajdi lebih singkat, efektif dan efisien;

c) Kualitas layanan berdasarkan kriteria dalam pelayanan SISKOHAT Gen 2 Versi 3 telah mencangkup prinsip prinsip atau ukuran kualitas layanan yaitu indikator tangible atau adanya bukti fisik berupa peralatan dalam penerapan layanan, lalu reability yang mencangkup dua hal utama yaitu konsistensi kerja dan kemampuan yang dipercaya, responsiveness atau bertanggung jawab dalam memberikan pelayanan, dan indikator terakhir adalah assurance atau kepastian adalah kualitas pelayanan yang diukur dari pengtahuan, kesopanan, dan kemampuan para petugas penyedia layanan dalam memberikan kepercayaan kepada pengguna layanan.

\section{Daftar Pustaka}

A. Parasuraman, Valarie A. Zeithaml, and Leonard L. Berry. (1988). "Servqual: A Multiple-Item Scale for Measuring Consumer Perceptions of Service Quality. Journal of Retailing, Vol 64 (1), pp 1237.

Abdullah, Edi. (2014). Prof Dr Agus Dwiyanto, MPA: Menekankan Inovasi Sektor Publik dalam Menghadapi Globalisasi. Kompasiana [Internet], 25 September 2014. Dapat diakses pada https://www.kompasiana.com/171717/54f4aa177 455137c2b6c8c15/prof-dr-agus-dwiyanto-mpamenekankan-inovasi-sektor-publik-dalammenghadapi-globalisasi [Diakses 10 Oktober 2016].

Caiden, Gerald E. (1970). Administrative Reform. London: Allen Lane The Penguin Press.

Dror, Yehezkel. (1970). Strategies for Administrative Reform. Santa Monica, CA: RAND Corporation.

Dwiyanto, Agus. (2004). Mewujudkan Good Governance Melalui Pelayanan Publik. Gadjah Mada University Press, Yogyakarta.

Keban, Jeremias, T. (2009). Kerjasama Antar Pemerintah Daerah dalam Era Otonomi: Isu Strategis, Bentuk, dan Prinsip. Tersedia pada https://www.bappenas.go.id/files/7713/5230/0987 /03yeremiastkeban_20091014131110_2258__ .pdf [Diakses pada 17 Mei 2017].

KEPMENPAN Nomor 63 Tahun 2003 tentang Pedoman Umum Penyelenggaraan Pelayanan Publik.

Mahmudi. (2015). Manajemen Kinerja Sektor Publik Edisi Kedua.Yogyakarta: UPP STIM YKPN.

Muluk, Khairul M.R. (2008). Knowledge Management (Kunci Sukses Inovasi Pemerintah Daerah). Malang: Banyumedia Publishing Bayumedia Publishing dengan Lembaga Penerbitan \& Dokumentasi FIA-UNIBRAW.

Nasucha, Chaizi. (2004). Reformasi Administrasi Publik Teori dan Praktek. Grasindo, Jakarta.

Peraturan Menteri Agama Nomor 30 Tahun 2013 tentang Bank Penerima Setoran Biaya Penyelenggaraan Ibadah Haji.

Peraturan Menteri Agama Republik Indonesia Nomor 29 Tahun 2015 tentang Perubahan Atas Peraturan Menteri Agama Nomor 14 Tahun 2012 tentang Penyelenggaraan Ibadah haji Reguler.

Peraturan Menteri Agama No.24 Tahun 2016 tentang Perubahan Peraturan Menteri Agama No 30 Tahun 2013 tentang Bank Penerima Setoran Biaya Penyelenggaraan Ibadah Haji.

Rosen. E. D. (1993). Improving Public Sector Productivity: Concept and Practice. Sage Publication, USA. 
Setyaningrum, Erna. (2009). Inovasi Pelayanan Publik. Surabaya: Medika Aksara Globalindo.

Suwarno, Yogi. (2008). Inovasi Di Sektor Publik. STIALAN Press, Jakarta.

Sumarto, Hetifah Sj. (2009). Inovasi, Partisipasi dan Good Governance. Yayasan Obor Indonesia, Jakarta. 